Article

\title{
Are Political Factors More Relevant Than Economic Factors in Firm-Level Renewable Energy Technology Export? Evidence from Path Analysis
}

\author{
Bongsuk Sung ${ }^{1}$ and Woo-Yong Song ${ }^{2, *}$ \\ 1 Department of International Trade, Kyonggi University, 154-42 Gwanggyosan-ro, Yeongtong-gu, \\ Suwon-si 16227, Gyeonggi-do, Korea; bsssung@kgu.ac.kr \\ 2 Department of Management and Accounting, Hanbat National University, 125 Dongseodae-ro, Yuseong-gu, \\ Daejeon 34518, Korea \\ * Correspondence: wysong@hanbat.ac.kr
}

Citation: Sung, B.; Song, W.-Y. Are Political Factors More Relevant Than Economic Factors in Firm-Level Renewable Energy Technology Export? Evidence from Path Analysis Sustainability 2021, 13, 8788. https:// doi.org/10.3390/su13168788

Received: 9 July 2021

Accepted: 2 August 2021

Published: 6 August 2021

Publisher's Note: MDPI stays neutral with regard to jurisdictional claims in published maps and institutional affiliations.

Copyright: (c) 2021 by the authors. Licensee MDPI, Basel, Switzerland. This article is an open access article distributed under the terms and conditions of the Creative Commons Attribution (CC BY) license (https:// creativecommons.org/licenses/by/ $4.0 /)$.

\begin{abstract}
Renewable energy technology (RET) firms are key economic entities in the export of RETrelated products and components, in which RET firms' exports are affected largely by policy and market. Nonetheless, the effects of policy and market factors on RET firm-level export have never received attention from researchers. This study aims to fill the gap by taking a political economy approach to establish a structural equation model to analyze the path of political-economic factorfirms' market orientation-based export. This study reveals that RET firms' market-orientation-based export enhancement depends entirely on political forces. Particularly, two government intervention instruments, environmental policy and export promotion policy, were highlighted. However, the effects of renewable energy policies on the exports of RET firms through market orientation are negative and statistically significant. This study proves that the effects of inter-firm competition and market attractiveness on RET firms' exports through their market orientation are negative and statistically significant and insignificant, respectively. Further, this study demonstrates that RET firms' market orientation has a significant positive effect on their export performance. We conclude that in order to improve RET-related policy effectiveness and efficiency, it will be useful to consider firms' heterogeneity in response to external factors. Additionally, a full mediation model in the academic investigation of the effects of various external factors, including public policies and market factors, on firm-level export, and the implementation of firm-level export-induced policy, taking into account firms' managerial interpretations to external factors, should be considered.
\end{abstract}

Keywords: export performance; market orientation; political-economic factors; renewable energy technology firms; structural equation modeling approach

\section{Introduction}

Renewable energy technologies (RETs) are crucial for environmentally sound and sustainable development (ESSD) signifying a normative message that economic growth should harmonize with environmental protection. Notably, to achieve ESSD, cost reduction through further technological innovations in RET-related products and components is vital for renewable energy power generation. However, technological and market uncertainty related to RETs [1-5] discourage RET firms from investing in innovation. Governments worldwide have been implementing policies to encourage RET firms to engage in innovation activities and enhance economic performance, which has prompted researchers to research the impact of public policies on economic performance in the RET industry. As constant improvements in export become more important in ensuring industrial growth in an open economy, whether public policies may end up leading exports is a central issue [6].

Most of the existing studies (e.g., [7-11]) empirically demonstrate that public policies help promote exports. However, to implement export-induced policy effectively and 
efficiently, policymakers need to specifically understand the policy-firm's response-export nexus and realize implications for RET firms, actual beneficiaries of public policy support, and key economic entities of export. Moreover, understanding that RET firms are closely associated with a successful transition to renewable energy-based economies, and that such a transition requires a stakeholder participatory approach [12-16], policymakers need to further grasp and consider the influence of stakeholders on the viability of RET firms, including a renewable energy system. This study fills this gap by applying a political economy approach in the analysis of firms.

According to the principle of the Rio Declaration on Environment and Development, the integrated and balanced consideration of socio-environmental, economic, political, and cultural issues is a core element for attaining sustainability in an open economy. This notion signifies that the issue of sustainability is transdisciplinary, comprising multiple perspectives such as environmental, political, sociocultural, economic, and financial aspects [17-19]. Numerous determinants are typically structured with political-economic forces in many conceptual frameworks for exploring sustainability [20,21]. Political-economic forces originate via various stakeholders who require legitimization of firms' activities through compliance with their beliefs and expectations [22-25], fulfilling the expectation of various interest groups [26]. Such political-economic contextual drivers are closely associated with the promotion of RETs, such as the enhancement of renewable energy capacity $[27,28]$, increased reliance on renewable sources [29], the implementation of bioenergy projects [14,30], innovation creation in the wind turbine [31] and photovoltaic [12] manufacturing industry, export improvements [11], and the transition to a renewable energy economy [13-16]. In the context of these studies, the current study analyzes the impact of political and economic factors on RET firms' exports.

Céspedes-Lorente et al. [32] and Hawn et al. [33] hold that firms must obtain two types of legitimacy: Sociopolitical legitimacy from non-market stakeholders and market legitimacy from market stakeholders. Sociopolitical legitimacy can be obtained by RET firms, through activities corresponding to sociopolitical expectations that demand substantial contribution of RETs toward the achievement of sustainability in society. The sociopolitical force emerges from the institutional environment $[24,34]$ applying formal coercive pressure, providing a clear signal to firms to promote RETs through promotional legislation or mandates and subsequently expecting active acceptance of its support in return [11]. Such public policies tend to reflect overall pressures from various non-market stakeholders in each country, since they are formed through interactions between various stakeholders and each country's government [35]. Each country primarily implements the RET industrial policy (REP), environmental policy (ENP), and export promotion policy (EXP) to achieve ESSD in an open economy. However, most existing studies (e.g., [8,10,11,35-37]) have generally appraised the influence of REP on export performance. Although some studies, such as Costantini and Crespi [7], Groba [36], and Kim and Kim [9], observed how REP and ENP influence export performance, the impact of the three policies-REP, ENP, and EXP—on exports has received little attention. Furthermore, almost all the literature, except Rammer et al. [10], empirically tests the effects of public policies on export performance at the industry level, despite the firms being the actual beneficiaries of public policies. This discrepancy indicates that the results of the industry-level studies, mainly focused on REP, are insufficient to provide policymakers with practical insights regarding the implementation of policy strategies to improve RET firms' export performance despite being key economic entities of export. Although Rammer et al. [10] scrutinized the nexus between REP and firms' exports, the examination of the effects of ENP and EXP on exports remains unaddressed at the firm level. In reality, each country adopts a REP, ENP, and EXP to constantly achieve environmental protection and economic growth by supporting RET firms. In this context, REP, ENP, and EXP, implemented as elements of the institutional environment in each country, are representative expectations derived from non-market stakeholders that require compliance from RET firms. These firms can obtain market legitimacy by seizing market or economic opportunities and seeking benefits [11] corresponding 
to market or economic expectations related to RETs. The economic forces originate from the economic environment [24], necessitating RET firms to actively respond to market signals expressed by market size and demand (e.g., [10,35]) and inter-firm competition (e.g., [11]). The aforementioned points, in the context of Wamsley and Zald [38,39], suggest that a RET firm is a business entity constrained by external political-economic forces concurrently responding to such restrictions, thereby enhancing performance.

The significant contribution of this study to the existing literature is threefold. First, policy and market factors are considered as the influences of firm-level export by applying a political economy perspective to firms. In particular, this study includes three policiesrenewable energy policy, environmental policy, and export promotion policy-along with market factors, by reflecting realistic RET-related policy to achieve ESSD in each open economy. In contrast, other existing studies only consider renewable energy policy as a unique influence of export at the industry level. No studies have considered external factors that influence RET firms' exports in the context of a political economy perspective. Second, we focus on the mediating effects of firms' responses to policy and market factors on export, by reflecting the significance of organizational actions through managerial interpretations to external environmental changes in performance enhancement, instead of the direct effect of only renewable energy policy on export examined in most existing studies at the industry level. Third, we propose more practical implications compared to existing studies for RET firms to promote as key economic entities of export of RET-related products and components.

The goal of this study is to empirically investigate the relative importance and priority of the external political (REP, ENP, and EXP) and economic (market attractiveness and interfirm competition) factors that may facilitate RET firms' exports through market orientation, employing a structural equation modeling (SEM) approach to survey-based data of Korean firms that manufacture RET-related products and components.

The remainder of this paper is organized as follows. In Section 2, we present the theoretical background and establish the hypotheses and model of the path from politicaleconomic factors-REP, ENP, EXP, inter-firm competition, and market attractiveness-to firms' export performance. Then, we measure the variables and describe the research methodology in Section 3, and in Section 4, we perform our empirical test, and present and interpret the results. We propose policy implications based on the results of the study in Section 5. Lastly, Section 6 gives concluding remarks.

\section{Theoretical Model}

Due to the relative immaturity and high cost compared to fossil fuels [40], RETs have much room for innovation. However, RET firms are reluctant to invest in innovation because of technological and market uncertainty [1-5], leading to the intervention of each government through the utilization of various policy instruments. As RETs are regarded as integral for ESSD, each government implements various policies targeting environmental and economic aspects associated with RETs, which enhance the profit (e.g., [12,41-44]) and export (e.g., [7-11,36]) of the RET industry and firms by promoting innovation (e.g., [45-52]). The results of the literature highlight that from a political-economic perspective, the government is crucial for spurring RET firms to proactively conduct various activities to penetrate local and export markets. This political force can signal lucrative business opportunities through promotional policy measures that endorse the expansion of RETs. Furthermore, the path from policy support to export through innovation indicates that in the context of inter-firm global competition, policy measures facilitate activities of RET firms to avail market opportunities [13], thereby promoting export performance.

According to Sung and Song [35], public policies are the outcome of interactions between the government and various interest groups in each country. Consistent with the observations of Céspedes-Lorente et al. [32] and Hawn et al. [33], public policies reflect representative expectations of various non-market stakeholders within society, requiring RET firms to secure sociopolitical legitimacy. To realize ESSD per the expectations of the 
Paris Agreement, each country aims to reduce global greenhouse gas emissions; hence, sustainable economic growth in an open economy is becoming increasingly necessary. In response to these issues, the Korean government endeavors toward economic and social transformation by promoting RETs and strengthening environmental regulations. According to the Ministry of Trade, Industry, and Energy (MOTIE) [53,54], the government's recent efforts to promote RETs are revealed by two types of policy strategies: To increase the competitiveness of RET firms by promoting efficiency enhancement through cost reduction, economies of scale, and technological innovation, and to promote firms' export activities. The former includes policy instruments to promote product quality enhancement, convergence technology development, production activity, investment expansion, public purchase, research and development (R\&D), infrastructure construction, and technological advancement. The latter contains policy instruments that promote the export of domestic product-linked overseas projects, export by strategic markets, overseas market selection of partnerships between power generation and manufacturing companies, overseas market selection for partnerships between large-, small-, and medium-sized firms, and preferential export financing. Environmental policies can also be associated with RET promotion in Korea to ensure ESSD, wherein encouraging renewable electricity production capacity is a strategic instrument. Therefore, ENP substantially contributes to the development of RET firms that produce RET-related products and components [7,36,55]. In 1963, Korea established the Pollution Prevention Act and amended the law in 1971. Despite the increasing pressure on the government to improve environmental protection, the law could not be effectively enforced until the 1970s, because the government was reluctant to strictly enforce environmental regulations owing to the concern of hampering industrial competitiveness [56]. However, the Korean government actively implemented the policy to curb the emission of pollutants based on the Environmental Conservation Act enacted in 1977, replacing the Pollution Prevention Act. Environmental regulation and administration have been intensified and systematized since 1994, when the Ministry of Environment (MOE) regulated all environmental affairs [56-60]. With the intensification of ENP, various efforts to decrease dependency on fossil fuels and to increase renewable energy capacity have been executed in Korea. This approach promotes the active study of RET firms to seize business opportunities in the local and export markets and consequentially improve domestic and international sales.

Economic forces require firms to obtain market or economic legitimacy [32,33], which usually comes from the main actors in the market, namely consumers and competitors [24]. Consumers and competitors signal firms in the industry to determine whether market value related to certain products and technologies increased. A high market value implies the availability of many lucrative business opportunities to firms in the industry served, requiring firms to proactively implement economic benefit-seeking activities. Market value is typically revealed by market attractiveness, a function of size, rate of market growth, and profitability. Regarding RETs, a sizable and stable market demand [7,8,10,13,35,61,62] can be interpreted as market acceptance in local and export markets, which drive RET firms' innovation and market orientation [11]. Notably, firms competitively conduct marketoriented organizational learning when market opportunities are high. Moreover, inter-firm spillovers of activities, and knowledge accumulated by competitors that can enhance market value, innovation, productivity, and profitability, also increase significantly [63,64]. Such a situation, where mimetic and competitive pressures are high, forces RET firms to adopt a more active and competitive market-oriented approach to the production and sales of RET-related products and components.

Holistically, the pressure to seize business opportunities in local and export markets is evident through public policies and market factors. The result of such firm-level learning is expressed as market orientation, which contributes to sustainable growth by enhancing export performance in the context of inter-firm global competition. Based on this perspective of organizational sustainability in an open economy, we employ the following structural equation model (refer to Figure 1) to explore the path running from political 
factors associated with RETs (environmental, energy, and export promotion policies) and economic determinants (inter-firm competition and market attractiveness), to the market orientation of RET firms, resulting in export performance.

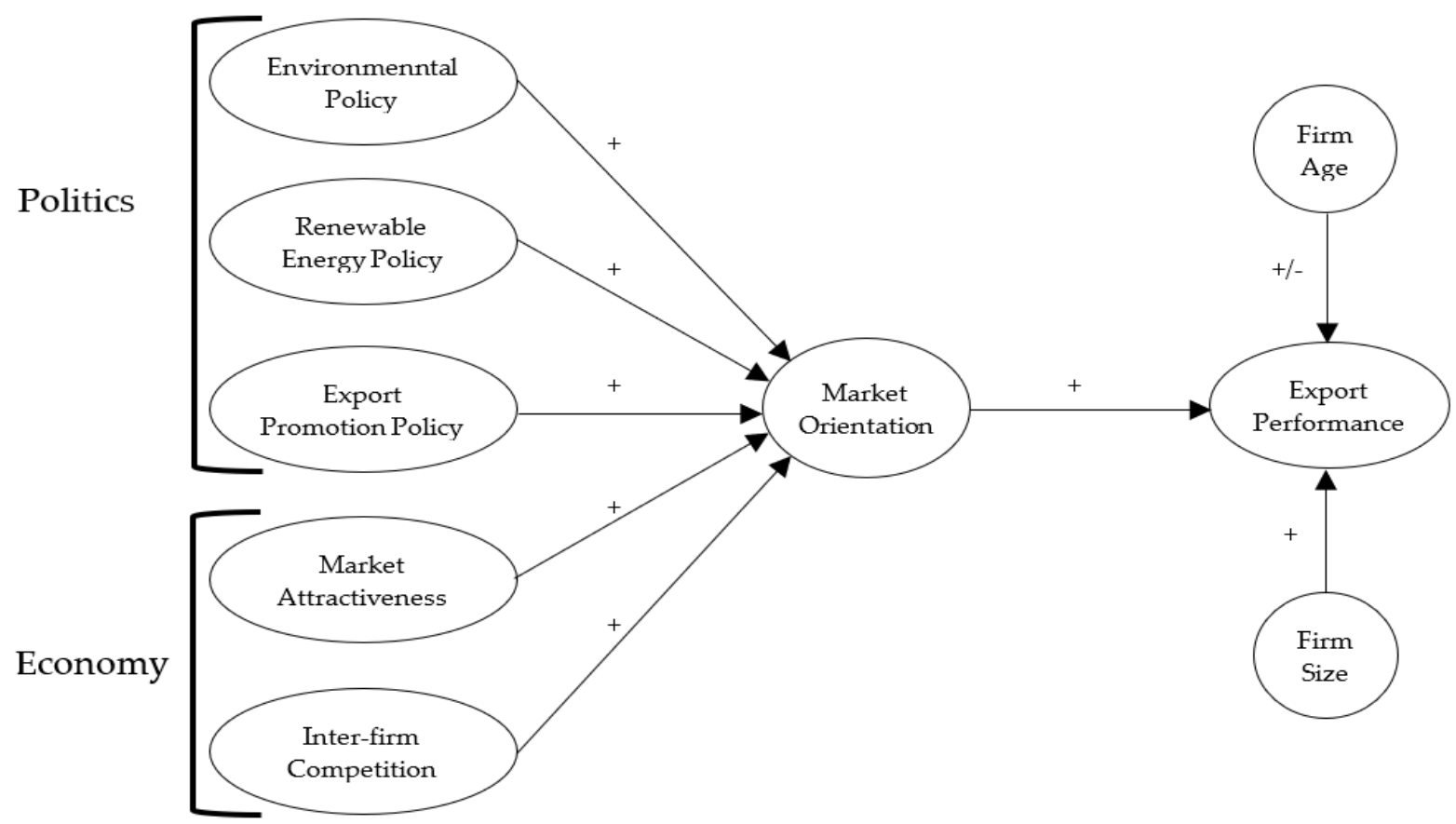

Figure 1. Theoretical model.

This study controls for the effects of omitted variables that may affect the path between political-economic factors, market orientation, and export performance through the inclusion of firm size and age in the model. According to the Organisation for Economic Co-operation and Development (OECD) [65] and Ruzzier and Ruzzier [66], larger firms conduct their innovation activities more effectively. Moreover, firm size is imperative for realizing scale economies, which means that an increase in the amount of production leads to reduced production costs and increased productivity. Thus, firm size is closely involved in the enhancement of export performance. The effect of firm age on performance, particularly innovation, is unclear in the literature. The organizational theory argues that firms' innovation is widely acknowledged as an outcome of organizational learning. Learning at the firm level is a procedure through which an organization gains experience and uses it to create innovation and gradually improve itself $[67,68]$. This correlation specifies that firms' experience denotes age [48] and that the effect of the firms' age on innovation also depends on learning effectiveness and efficiency [69-71]. Considering the argument of heterogeneous firm trade theory (i.e., export growth is based on productivity enhancement induced by innovation), firm age can positively or negatively affect exports.

\section{Measures, Data Collection, and Research Methodology}

\subsection{Measures and Data Collection}

Government policies support the RET firms through ENP, REP, and EXP, and expect active acceptance of their support [35]. Therefore, ENP, REP, and EXP are essential for promoting RET firms to actively utilize policy instruments to enhance their competitive advantage in the respective industry.

ENP is usually defined by the extent to which it restricts [72] or promotes firms' innovation [73]. However, the ENP's goal is to achieve ESSD in society, meaning that ENP substantially contributes to the development of RET firms that produce RET-related products and components. In this context, ENP is defined as the intensity of promotion concerning ESSD in society, along with RET firms' development. This specific policy is 
assessed via seven items based on the studies of Costantini and Crespi [8], Dechezleprêtre et al. [55], Groba [36], Jaffe and Palmer [74], and Jaffe et al. [75]: (ENP1) Environmental regulation is very strict; (ENP2) environmental regulation helps achieve environmentally sound and sustainable growth in society; (ENP3) various environmental regulations are imposed; (ENP4) environmental regulation contributes to energy transition of society; (ENP5) environmental regulation promotes the firm's business opportunity; (ENP6) environmental regulation promotes the firm's profitable activities; and (ENP7) environmental regulation facilitates innovation in the energy system of society. Based on the work of Cui et al. [45], Hoppmann [46], Plank and Doblinger [47], and Sung [48], this research defined REP as the intensity of promotion related to innovation of RET firms in terms of each policy instrument. Besides, REP was assessed through ten items, considering the policy instrument that the Korean government implements based on MOTIE [53,54]: (REP1) REP promotes the firm's overall innovation; (REP2) eco-friendly support in the product lifecycle promotes the firm's innovation; (REP3) support for product quality enhancement enhances the firm's innovation; (RE4) support for convergence technology development helps improve the firm's innovation; (REP5) support for production activity promotion increases the firm's innovation; (REP6) support for investment expansion contributes to the firm's innovation; (REP7) support through public purchase helps improve the firm's innovation; (REP8) R\&D support contributes to the firm's innovation; (REP9) support for infrastructure construction increases the firm's innovation; and (REP10) support for technological advancement contributes to the firm's innovation. EXP is determined as the intensity of promotion related to firms' export activity in line with Broocks and van Biesebroek [76], Van Biesebroeck et al. [77], and Martinez-Roman et al. [78]. This policy is measured via six items, considering the policy instrument that the Korean government implements based on MOTIE [53,54]: (EXP1) EXP is very useful for the firm; (EXP2) support for export of domestic product-linked overseas projects promotes the firm's export activity; (EXP3) customized policy support by strategic markets helps the firm's export activity; (EXP4) preferential export finance support contributes to the firm's export activity; (EXP5) support for overseas market selection of partnership between power generation and manufacturing company improves the firm's export activity; and (EXP6) support for overseas market selection for partnership between large-, small-, and medium-sized firms contribute to the firm's export activity.

Unlike political forces that require firms to conduct their activities legitimately and consistently with the government's expectations, firms' external economic forces-interfirm competition (COM) and market attractiveness (MAA)—pressurize firms to seek economic rent through inter-firm competition and secure business opportunities from the market [24]. This paper defined COM as the competition intensity, which means that firms compete with each other to develop and produce high-quality technologies and products. This competitiveness is assessed with six items based on Costantini et al. [49] and Martinez-Roman et al. [78]: (COM1) Inter-firm competition for developing technologies and products is fierce; (COM2), competitors are very aggressive in conducting innovative activities; (COM3) there is fierce competition for product differentiation among competitors; (COM4) competition for overall cost reduction is fierce; (COM5) the number of products increases; and (COM6) there is fierce competition for new investments. MAA is identified as the potential benefit of manufacturing RETs, and is measured through six items based on Costantini and Crespi [7], Costantini and Mazzanti [8], Marques and Fuinhas [26], Lewis and Siser [79], Lund [62], Sung and Cui [11], and Sawhney and Kahn [80]: (MAA1) Current market size of renewable energy technology related to products and components is very large; (MAA2) potential demand for renewable energy technology related to products and components is very diverse; (MAA3) potential market size of renewable energy technology related to products and components is very diverse; (MAA4) potential market size of renewable energy technology related to products and components can lead to a high profit for the firm; and (MAA5) the number of consumers who support renewable energy continuously increases. 
This study established firms' market orientation (FMO) as the degree of activities or efforts that they perform to seize opportunities in both local and export markets. This orientation was assessed via five items based on the efforts of Kohli and Jaworski [81], Morgan et al. [82], and Murray et al. [83]: (FMO1) We implement various strategies to enhance customers' value; (FMO2) we conduct organizational learning to better understand market demand; (FMO3) we appropriately use market information to produce products and components; (FMO4) we quickly respond to changes in the market environment; and (FMO5) we perform $R \& D$ activities to reflect technology trends appropriate for market conditions. Firms' export performance (EXPER) is measured based on the study of Rammer et al. [10], incorporating the contribution ratio of overseas sales to total sales. This study assessed firm size (FSI) with regards to the number of employees following Ruzzier and Ruzzier [66] and Verwaal and Bonkers [84] and measured firm age (FAG) in relation to the number of years since registration $[10,43,47,48]$.

The items integrated to measure each construct, except FSI, FAG, and EXPER, consisted of a fixed-response questionnaire using a five-point Likert scale, ranging from 1 (strongly disagree) to 5 (strongly agree). We performed a purposive sampling of firms that specialize in manufacturing RET-related products and components in seven RET sectors (see details below). We aggregated a total of 252 usable firm responses from a survey conducted in Korea over the duration of one month (i.e., from 1 through 30 July 2020), containing responses from 3, 204, 12, 10, 3, 4, and 16 firms in solar thermal, solar photovoltaic, wind, geothermal, hydro energy, bioenergy, and fuel cell, respectively.

\subsection{Research Methodology}

Based on self-reporting scales, the common method variance (CMV) must be checked, which incurs bias in the examination of relationships between the variables [85,86]. We employ Harman's [87] one-factor test to confirm whether CMV is an issue. Subsequently, we employ the SEM approach to test the path running from political factors associated with RETs (environmental, energy, and export promotion policies) and economic factors (inter-firm competition and market attractiveness) to the market orientation of firms. To this end, we employ a two-stage model building process proposed by Hair et al. [88] and Hoyle [89]: Confirmatory factor analysis to investigate the reliability and validity of the measurement model, and analysis of the path between the variables of the structural model (for the detailed research methodology and procedure, see Figure A1 of Appendix A).

\section{Empirical Analysis}

We performed Harman's [87] one-factor test by including all the survey items in an exploratory factor analysis to check CMV before using the SEM approach to test the path between the variables in question. The test results demonstrated that CMV is not an issue in this study, by showing that one factor accounts for $26.227 \%$ of the variance in the sample.

To obtain the reliability and validity of the measurement model, we administered a confirmatory factor analysis of the data. The final result confirms that the data are well fit for the proposed measurement model, showing $\chi^{2}=258.757(p=0.000 ; d f=155)$, $\chi^{2} / d f=1.669, \mathrm{CFI}=0.967, \mathrm{SRMR}=0.047$, and RMSEA $=0.052$ (refer to Table 1 ) and fulfilling Hair et al.'s [90] criteria in a model with more than 30 observed variables and 250 observations (as in the case of this study): $\chi^{2}$ is significant, CFI is more than 0.9, SRMR is 0.8 or less, with CFI above 0.92 , and RMSEA is less than 0.07 , with CFI of 0.9 or higher. Other fit indices $(\mathrm{GFI}=0.908, \mathrm{AGFI}=0.876, \mathrm{TLI}=0.960, \mathrm{RFI}=0.906, \mathrm{NFI}=0.923, \mathrm{IFI}=0.968$ ) proposed by Bentler and Bonett [91], Kline [92], and Thompson [93] also validated that the measurement model was adequately fit for the data. 
Table 1. Measurement model's confirmatory factor analysis.

\begin{tabular}{|c|c|c|c|c|c|c|c|}
\hline Latent Variables & Items & FL & SE & $T$-Value & CR & AVE & Cronbach's $\alpha$ \\
\hline \multirow[t]{2}{*}{ ENP } & ENP2 & 0.682 & & & 0.939 & 0.886 & 0.654 \\
\hline & ENP7 & 0.715 & 0.126 & 8.251 & & & \\
\hline \multirow[t]{4}{*}{ REP } & REP1 & 0.754 & & & 0.975 & 0.908 & 0.823 \\
\hline & REP2 & 0.792 & 0.082 & 11.991 & & & \\
\hline & REP3 & 0.722 & 0.069 & 10.957 & & & \\
\hline & REP6 & 0.680 & 0.070 & 10.300 & & & \\
\hline \multirow[t]{3}{*}{ EXP } & EXP3 & 0.746 & & & 0.968 & 0.898 & 0.786 \\
\hline & EXP4 & 0.789 & 0.100 & 10.797 & & & \\
\hline & EXP5 & 0.700 & 0.089 & 9.910 & & & \\
\hline \multirow[t]{2}{*}{$\mathrm{COM}$} & COM1 & 0.698 & & & 0.917 & 0.849 & 0.725 \\
\hline & COM3 & 0.865 & 0.212 & 5.410 & & & \\
\hline \multirow[t]{4}{*}{ MAA } & MAA1 & 0.751 & & & 0.974 & 0.905 & 0.806 \\
\hline & MAA2 & 0.736 & 0.070 & 10.454 & & & \\
\hline & MAA3 & 0.715 & 0.071 & 10.206 & & & \\
\hline & MAA4 & 0.697 & 0.078 & 9.718 & & & \\
\hline \multirow[t]{5}{*}{ FMO } & FMO1 & 0.937 & & & 0.993 & 0.967 & 0.972 \\
\hline & FMO2 & 0.931 & 0.038 & 28.666 & & & \\
\hline & FMO3 & 0.947 & 0.035 & 30.653 & & & \\
\hline & FMO4 & 0.958 & 0.035 & 32.335 & & & \\
\hline & FMO5 & 0.902 & 0.040 & 25.620 & & & \\
\hline
\end{tabular}

Note: Fit indexes: $\chi^{2}=258.757(p=0.000 ; d f=155), \chi^{2} / d f=1.669, \mathrm{CFI}=0.967$, SRMR $=0.047, \mathrm{RMSEA}=0.052 . \mathrm{FL}, \mathrm{SE}, \mathrm{CR}$, and AVE denote factor loading, standard error, composite reliability, and average variance extracted, respectively.

Tables 1 and 2 depict that measurement model data are valid and reliable. The findings of convergent validity presented in Table 1 prove that all data are reliable. All items for each construct had factor loadings over 0.6 , and all composite reliabilities are more than 0.9 for each construct, which satisfies the criteria of 0.7 recommended by Bagozzi and Yi [94] and Hair et al. [88]. All values of the extracted average variance-which is the percentage of the variance of each construct explained by individual items-are above 0.8 , which is higher than 0.5, as recommended by Bagozzi and Yi [94] and Fornell and Larcker [95]. Table 2 exhibits that multicollinearity is not an issue since no pair of measures with correlations exceeded 0.9. Additionally, all constructs have discriminant validity because the squared correlation between constructs is lower than the value of the extracted average variance value for any of the two constructs [92,95].

Table 2. Latent constructs correlations.

\begin{tabular}{|c|c|c|c|c|c|c|}
\hline & 1 & 2 & 3 & 4 & 5 & 6 \\
\hline ENP & 0.886 & & & & & \\
\hline REP & $\begin{array}{l}0.739^{* * *}(0.54) \\
{[0.04]}\end{array}$ & 0.908 & & & & \\
\hline EXP & $\begin{array}{l}0.161 *(0.02) \\
{[0.02]}\end{array}$ & $\begin{array}{l}0.597^{* * *}(0.35) \\
{[0.03]}\end{array}$ & 0.898 & & & \\
\hline $\mathrm{COM}$ & $\begin{array}{l}-0.176 *(0.03) \\
{[0.02]}\end{array}$ & $\begin{array}{l}0.115^{* *}(0.01) \\
{[0.02]}\end{array}$ & $\begin{array}{l}0.246^{* * *}(0.06) \\
{[0.02]}\end{array}$ & 0.849 & & \\
\hline MAA & $\begin{array}{l}0.388^{* * *}(0.15) \\
{[0.03]}\end{array}$ & $\begin{array}{l}0.471^{* * *}(0.22) \\
{[0.04]}\end{array}$ & $\begin{array}{l}0.428^{* * *}(0.18) \\
{[0.03]}\end{array}$ & $\begin{array}{l}0.365^{* * *}(0.13) \\
{[0.03]}\end{array}$ & 0.905 & \\
\hline FMO & $\begin{array}{l}0.109(0.01) \\
{[0.04]}\end{array}$ & $\begin{array}{l}0.237^{* * *}(0.05) \\
{[0.04]}\end{array}$ & $\begin{array}{l}0.450^{* * *}(0.20) \\
{[0.04]}\end{array}$ & $\begin{array}{l}0.128 *(0.01) \\
{[0.04]}\end{array}$ & $\begin{array}{l}0.233^{* * *}(0.05) \\
{[0.05]}\end{array}$ & 0.967 \\
\hline
\end{tabular}

Note: The figures in parentheses are $\rho^{2}$. The figures in brackets are standard errors. Bold diagonal figures are the square roots of AVE. ${ }^{* * *}$,

$* *$, and ${ }^{*}$ denote $1 \%, 5 \%$, and $10 \%$ significance levels, respectively.

Figure 2 reports the results of the structural model of the relationships between firms' external political-economic force, market orientation, and export performance while controlling for firm size and firm age. The values of the goodness-of-fit indices, $\chi^{2}=319.465$ $(p=0.000 ; d f=204), \chi^{2} / d f=1.566, \mathrm{CFI}=0.967$, SRMR $=0.046$, and RMSEA $=0.047$, 
exceeded Hair et al.'s [90] threshold criteria. Other indices, GFI $=0.903$, AGFI $=0.868$, $\mathrm{TLI}=0.957, \mathrm{RFI}=0.901, \mathrm{NFI}=0.911$, and IFI $=0.966$, also met the criteria recommended by Bentler and Bonett [91], Kline [92], and Thompson [93]. The parameter estimates show that FMO is positively affected by external political forces, in particular, ENP and EXP at the $1 \%$ significance level, and an external economic force, MAA, at the $10 \%$ significance level. Nevertheless, the results confirm that REP negatively affects FMO at the 1\% significance level and that COM is insignificant. Considering that the coefficients of ENP and EXP are relatively high compared to that of COM, these findings indicate that RET firms' market orientation is mainly affected by public policy in Korea, especially environmental and export promotion policies.

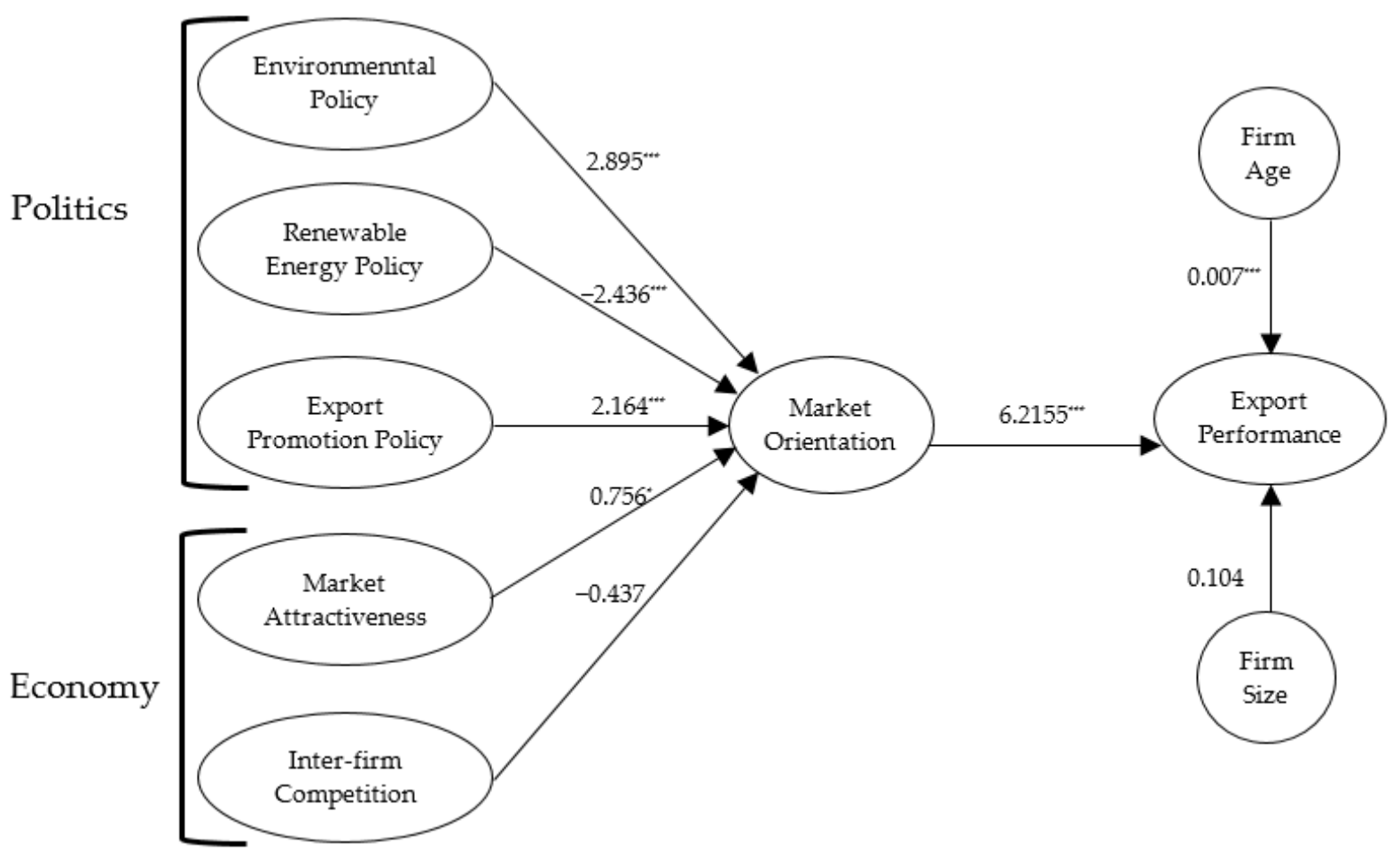

Figure 2. The structural model estimation. Notes: $\chi^{2}=319.465(p=0.000 ; d f=204), \chi^{2} / d f=1.566, \mathrm{CFI}=0.967, \mathrm{SRMR}=$ $0.046, \mathrm{RMSEA}=0.047, \mathrm{GFI}=0.908, \mathrm{AGFI}=0.876, \mathrm{TLI}=0.960, \mathrm{NFI}=0.923, \mathrm{IFI}=0.968 .{ }^{* *}$ and $*$ denote $1 \% 10 \%$ significance levels, respectively.

Table 3 illustrates the effects of political-economic factors on export performance through market orientation in the structural model. The results of this study elucidate that FMO has a positive effect on EXPER directly at the $1 \%$ significance level. Public policies (i.e., ENP and EXP) still positively influence EXPER through FMO at the 1\% significance level. However, REP negatively affects export at the $1 \%$ significance level. Although the coefficient is very small, the FSI positively impacted EXPER. However, MAA harms EXPER through FMO at the $10 \%$ significance level, and the COM was insignificant. These findings express that the export growth of RET firms is caused only by market orientation in response to environmental and export promotion policies and firms' orientation.

Table 3. The path from political-economic factors to export through market orientation.

\begin{tabular}{lll}
\hline Path of Observed Variables & Path Coefficient (Unstandardized) & $p$-Value \\
\hline $\mathrm{ENP} \rightarrow \mathrm{FMO} \rightarrow$ EXPER & 17.992 & 0.004 \\
$\mathrm{REP} \rightarrow \mathrm{FMO} \rightarrow \mathrm{EXPER}$ & -15.138 & 0.002 \\
$\mathrm{EXP} \rightarrow \mathrm{FMO} \rightarrow \mathrm{EXPER}$ & 13.450 & 0.001 \\
$\mathrm{COM} \rightarrow \mathrm{FMO} \rightarrow$ EXPER & 4.699 & 0.222 \\
$\mathrm{MAA} \rightarrow \mathrm{FMO} \rightarrow$ EXPER & -2.718 & 0.055 \\
\hline
\end{tabular}




\section{Discussions}

The main results and implications of this study are as follows. First, the results of the structural model (see Figure 2) indicate the importance of a full mediation model in the investigation of the effects of various external factors, including public policies and market factors, on export (the result of the structural model of a partial mediation did not acquire the values of the goodness-of-fit indices able to meet various criteria proposed by the existing studies [90-93], which is available upon request from the authors). The result of this study, the significance of firms' response to environmental factors, is similar to the results or arguments of previous studies (e.g., [13,96-99] that explore the influence of external factors on firms' responses. According to Dechezleprétre and Sato [96], productive investments of firms are triggered by environmental policies, which in turn affect their technology innovation and export outcomes. REP support (e.g., R\&D subsidies, feedin tariffs, quantity restrictions) not only has an important role as an additional input but also facilitates additional investment [97-99]. Firms respond to social demand by conducting innovation activities, such as developing a process and solution, which offers a new opportunity for competitiveness enhancement of RET-firms [13]. In light of the results of these studies, the findings of this study offer additional empirical evidence from an integrated perspective. In this context, this study evinces the importance of firms' active study to seize market opportunities for business growth promoting the performance of relevant exports by demonstrating that RET firms' market orientation positively affects their export performance at the $1 \%$ significance level. This interlinkage suggests that firms should make great efforts to create positive conditions for marketorientation-driven gains by constantly conducting various market-oriented activities based on active organizational learning, to study market opportunities in the inter-firm global competition setting. Such activities should be performed in all primary and support activities in the value chain. Furthermore, the result of this study suggests that to implement firm-level export-induced policy effectively and efficiently, policymakers should make great efforts to fully understand and consider RET firms' managerial interpretations of their external environmental changes derived from various political-economic factors.

Second, this study revealed that only two policies, ENP and EXP, are positive and statistically significant in improving RET firms' exports by increasing their market orientation. This notion implies that the competitiveness of RET firms still depends entirely on two government intervention instruments and not the market. These findings are consistent with the results of Costantini and Crespi [7], Groba [36], and Kim and Kim [9] regarding the renewable energy industry, supporting porter and van der Linde's [73] hypothesis that environmental regulation is a significant driver behind comparative advantage. The findings offer additional empirical evidence to RET firms in the context of the studies of Broocks and van Biebroeck [76] demonstrating the significance of public policy to promote the export market entry of manufacturing firms. In light of the results of the previous studies, the findings of this study indicate that environmental policy and export promotion policy prompt RET firms to enhance innovation-based productivity leading to export growth. The outcomes demonstrate that a single unit increase in ENP and EXP will increase RET firms' exports through their market orientation by 17.99 units and 13.45 units at the $1 \%$ significance level, respectively. Considering the estimated coefficients of the two policies, the ENP and EXP should be continuously and reliably implemented, thereby improving the chance of RET firms to seize market opportunities for business growth in the context of inter-firm global competition.

Third, this study outlined the effects of REP on RET firms' exports through their market orientation as negative and statistically significant. REP used in testing the structural mode of this study mainly consists of support for product quality enhancement, eco-friendly support in the product lifecycle, and investment expansion support. RET firms' market expansion and competitiveness enhancement through such policy instruments additionally require government policy that helps to boost the renewable energy installation capacity, such as a feed-in tariff, mandated installation, or a production quota [48]. These instruments 
promote the consumption of RET-related products and components of power generation installers and power generation companies. In this context, the result of this study reflects Korea's situation where market-pull instruments do not properly work, which is not irrelevant to the negative significant impact of MAA and COM on export through market orientation (see Table 3). Considering the aforementioned points, the finding of this study is similar to that of Rammer et al. [10] showing that almost all energy policy instruments (taxation, regulation, standard agreements, subsidy, and energy technology development) are insignificant in promoting firms' export activity, but the demand-side instrument is significant and negative. Based on Cui et al. [45], Hoppmann [46], Plank and Doblinger [47], and Sung [48], the rationale for REP is to promote RET firms' innovative activities and efforts, which leads to productivity-based export enhancement. In reality, RET firms are confined in an atmosphere of underinvestment for innovation, because of uncertainties related to technology and markets [1-5]. Thus, a positive dynamic path running from policy to export is achieved only when the policy incentives are so large that a situation of underinvestment can be overshadowed by a promising investment situation. Considering the argument of a political economy framework [38,39], stating that firms' performance enhancement is caused by actively responding to their external pressures, the results of this study suggest that policy strategies related to RETs should be devised and implemented to enable RET firms to proactively invest in innovation.

Fourth, this study shows the effects of MAA and COM on RET firms' exports through their market orientation are negative and statistically significant, and insignificant, respectively. According to Lund [63], the successful expansion of the domestic RET market increases export specialization. The favorable market conditions of RET-related products and components are expressed by sizable and stable market demand $[7,8,10,35,61,62]$, which is closely related to the size of renewable energy power capacity in society. Renewable energy capacity can be expanded using feed-in tariff policy measures $[12,62,100]$. When feed-in tariff payments are reduced, renewable energy power capacity shrinks, and the expected return of investment and financing in power generation decreases [101]. Furthermore, innovation in RETs will never occur if feed-in tariff measures do not work [51]. The negative and negligible effects of market factors signify that the Korean government's policy to expand its renewable installed capacity does not work properly. This notion is affirmed by the fact that the ratio of renewable energy contribution to primary energy supply is relatively low, compared to those of other OECD countries [102,103]. To facilitate a greater deployment of renewable electricity in Korea, more active consumer engagement is necessary [104]. The results suggest that the government should make great efforts to devise and implement various policy instruments to increase its demand for renewable energy, and for equipment and machinery to boost renewable installed capacity, thereby improving RET firms' market-oriented activities. Furthermore, this study establishes that inter-firm competition has a significant and positive effect on firms' market orientation, but this influence does not lead to exports. Usually, inter-firm competition in the product market increases firms' innovation activity-based productivity [105,106], which enhances exports. The results of this study, in the context of heterogeneous trade theory, imply that inter-firm competition is not high enough to go beyond the cutoff of productivity through innovation in the domestic market. Hence, various policy strategies and instruments to promote effective inter-firm competition within the RET industry should be formulated and implemented.

\section{Conclusions}

This study investigates how political and economic factors influence exports of RET firms through market orientation using survey-based data of 252 Korean RET firms that manufacture RET-related products and components. We confirmed the nonexistence of common method variance. To test the relationships, we employed a structural equation modeling approach wherein a two-stage model building process was applied. We conducted a confirmatory factor analysis to gauge the reliability and validity of the mea- 
surement model. Afterward, we analyzed the paths between the variables of the structural model.

RET firms are actual beneficiaries of policy support and key economic entities of export. Furthermore, RET firms are closely associated with the successful transition to renewable energy-based economies. Such a transition also requires a stakeholder participatory approach. This urges policymakers to understand and consider the influence of various political-economic factors on the viability of RET firms in an open economy. Nonetheless, almost all the existing literature has focused on the effect of only renewable energy policy on export at the industry level, which cannot provide policymakers with practical insights required to implement firm-level export-induced policy effectively and efficiently. The study considers points disregarded by existing studies and empirically investigates the effects of the political (renewable energy, environmental, and export promotion policy) and economic (market attractiveness and inter-firm level) factors on export by using an SEM modelling approach. This study contributes to the understanding of the relationships between various factors and firm-level export by offering additional theoretical arguments and empirical evidence to the existing literature. In particular, this study presents the most important academic and practical insights necessary to consider through a full mediation model in the academic investigation of the effects of various external factors, including public policies and market factors, on firm-level export, and the implementation of firm-level export-induced policy taking into account firms' managerial interpretations to external factors. However, the results of this study, especially the parameter estimates, should be interpreted while considering the following limitations. First, this study is Korea-specific. The relevant importance of the effects of policy and market factors on firm-level export and firms' responses to the external factors depends entirely on the different situations each country faces. Accordingly, future research should be conducted at the single country and firm level. Second, considering that energy transition, including viability of RET firms, requires a stakeholder participatory approach [12-16], the firm-level examination of the relationships between external factors and export should consider pressures or acts of a wider range of stakeholders, such as trade associations, nongovernmental organizations, civil societies, etc. This is expected to provide each government with more realistic insights to improve RET-related policy effectiveness and efficiency.

Author Contributions: B.S. and W.-Y.S. conceived the research idea and established the theoretical model. B.S. estimated the empirical model. B.S. and W.-Y.S. discussed these findings. All authors have read and agreed to the published version of the manuscript.

Funding: This research received no external funding.

Institutional Review Board Statement: Not applicable.

Informed Consent Statement: Not applicable.

Data Availability Statement: The data presented in this study are available on request from the corresponding author.

Acknowledgments: The authors need to express their gratitude to the anonymous reviewers of this journal for his/her valuable comments and suggestions that helped them improve the manuscript. Special gratitude also goes to the Editor who gave them the opportunity to revise their work.

Conflicts of Interest: The authors declare no conflict of interest. 


\section{Appendix A}

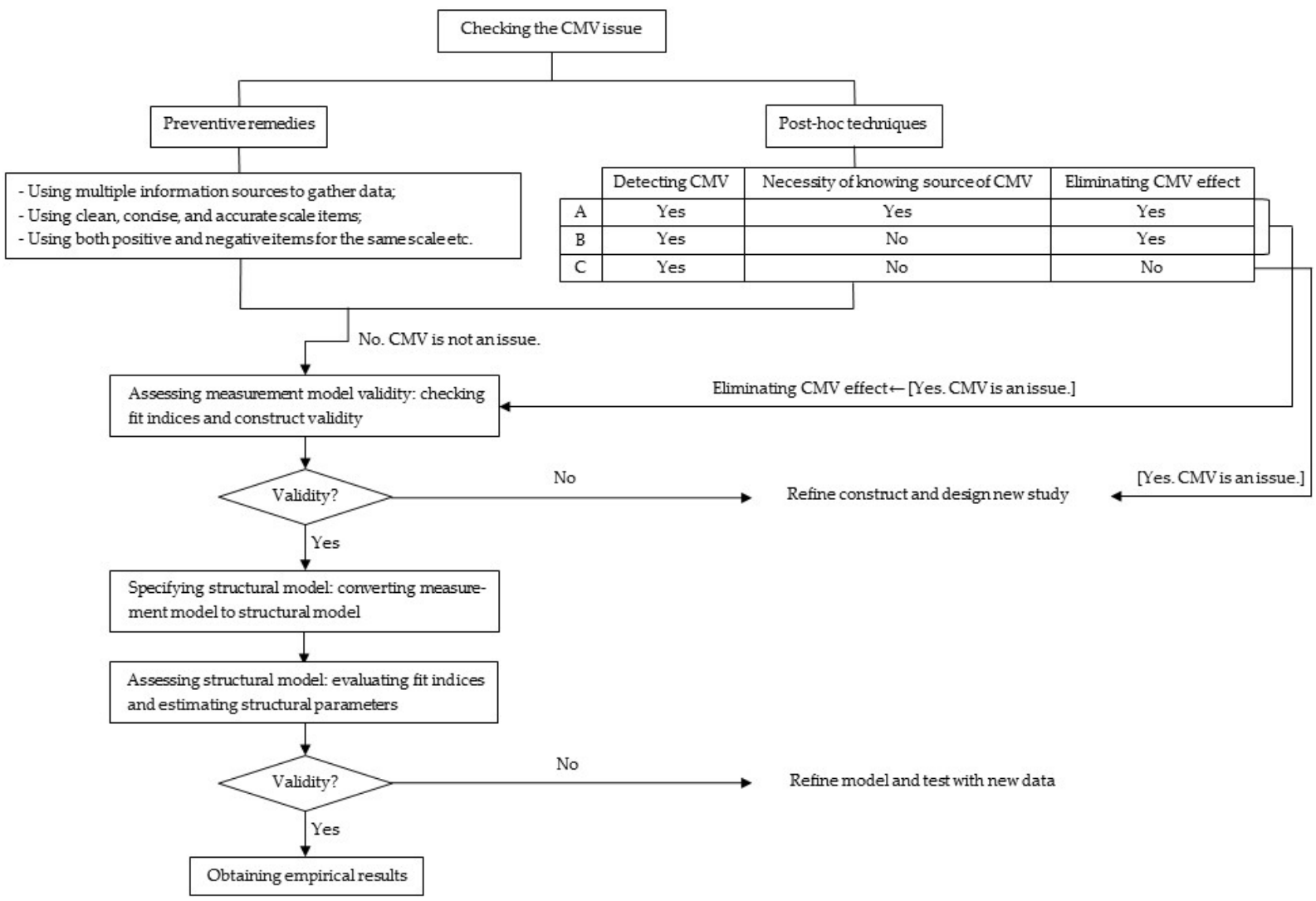

Figure A1. Research methodology and procedure. Source: The authors' arrangement based on Hair et al. [88], Hoyle [89], Podsakoff et al. [85], and Rodríguez-Ardura and Meseguer-Artola [86]. Notes: Pos-hoc techniques to check the CMV issue are categorized into $\mathrm{A}, \mathrm{B}$, and $\mathrm{C}$, in which $\mathrm{A}$ includes a directly measured latent factor method and measured response style technique; B contains a correlation-based marker technique, general factor covariate technique, CFA marker technique, and an unmeasured latent method factor technique; and C comprises Harman's single-factor test and correlation matrix procedure (for the detailed explanation, see Rodríguez-Ardura and Meseguer-Artola [86]).

\section{References}

1. Foxon, T.J.; Gross, R.; Chase, A.; Howes, J.; Arnall, A.; Anderson, D. UK innovation systems for new and renewable energy technologies: Drivers, barriers and systems failures. Energy Policy 2005, 33, 2123-2137. [CrossRef]

2. Jalonen, H. The uncertainty of innovation: A systematic review of the literature. J. Manag. Res. 2012, 4, 1-47. [CrossRef]

3. Luding, S.; Schmid, E.; Haller, M.; Bauer, N. Assessment of transformation strategies for the German power sector under the uncertainty of demand development and technology availability. Renew. Sustain. Energy Rev. 2015, 46, 143-156. [CrossRef]

4. Popp, D.; Newell, R.G.; Jaffe, A.B. Energy, the Environment, and Technological Change. In Handbook of the Economics of Innovation; Hall, B., Rosenberg, N., Eds.; Elsevier: North-Holland, The Netherlands, 2010; Volume 2, pp. 873-937.

5. Rout, U.K.; Blesl, M.; Fahl, U.; Remme, U.; Vos, A. Uncertainty in the learning rates of energy technologies: An experiment in a global multi-regional energy system model. Energy Policy 2009, 37, 4927-4942. [CrossRef]

6. REN21. Renewables Global Status Report: 2010; REN21 Secretariat: Paris, France, 2010.

7. Costantini, V.; Crespi, F. Environmental regulation and the export dynamics of energy technologies. Ecol. Econ. 2008, 66, 447-460. [CrossRef]

8. Costantini, V.; Mazzanti, M. On the green and innovative side of trade competitiveness? The impact of environmental policies and innovation on EU exports. Res. Policy 2012, 41, 132-153. [CrossRef]

9. Kim, K.; Kim, Y. Role of policy in innovation and international trade of renewable energy technology: Empirical study of solar PV and wind power technology. Renew. Sustain. Energy Rev. 2015, 44, 717-727. [CrossRef]

10. Rammer, C.; Gottschalk, S.; Peneder, M.; Wörter, M.; Stucki, T.; Arvanitis, S. Does energy policy hurt international competitiveness of firms? A comparative study for Germany, Switzerland and Austria. Energy Policy 2017, 109, 154-180. [CrossRef]

11. Sung, B.; Cui, W. Causal dynamic relationships between political economic factors and export performance in the renewable energy technologies market. Energies 2018, 11, 874. [CrossRef] 
12. D'Adamo, I.; Falcone, P.M.; Gastaldi, M.; Morone, P. The economic viability of photovoltaic systems in public buildings: Evidence from Italy. Energy 2020, 207, 118316. [CrossRef]

13. Dialga, I. Evaluating Normandy's sustainable development and energy transition policy. J. Clean. Prod. 2021, 305, 127096.

14. Felcone, P.M. Analysing stakeholders' perspectives towards a social-technical change: The energy transition journey in Gela Municipality. AIMS Energy 2018, 6, 645-657. [CrossRef]

15. Höfer, T.; Madlener, R. A participatory stakeholder process for evaluating sustainable energy transition scenarios. Energy Policy 2020, 139, 111277. [CrossRef]

16. Sung, B.; Park, S.-D. Who drives the transition to a renewable-energy economy? Multi-actor perspective on social innovation. Sustainability 2018, 10, 448. [CrossRef]

17. Barbier, E.B.; Burgess, J.C. The sustainable development goals and the systems approach to sustainability. Economics 2017, 11, 2017-2028. [CrossRef]

18. Dietz, S.; Neumayer, E. The legitimizing effect of social and environmental disclosure-A measurement. Ecol. Econ. 2007, 62, 617-626. [CrossRef]

19. Gallopín, G. A Systems Approach to Sustainability and Sustainable Development; United Nations: Santiago, Chile, 2003.

20. Davidson, K. A typology to categorize the ideologies for actors in the sustainable development debate. Sustain. Dev. 2014, 22, 1-14. [CrossRef]

21. Gale, F.P. The Political Economy of Sustainability; Edward Elgar: Cheltenham, UK, 2018.

22. Collinson, P. Livelihoods and Conflict: Case Studies in Political Economy Analysis for Humanitarian Action; ODI: London, UK, 2003.

23. Deegan, C. Introduction: The legitimizing effect of social and environmental disclosures-A theoretical foundation. Account. Audit. Account. J. 2002, 15, 281-311. [CrossRef]

24. Harrison, J.A.; Rouse, P.; De Villiers, C.J. Accountability and performance measurement: A stakeholder perspective. JCC: Bus. Econ. Res. J. 2012, 5, 243-258. [CrossRef]

25. Oliver, C. The influence of institutional and task environment relationships on organizational performance: The Canadian construction industry. J. Manag. Stud. 1997, 34, 99-124. [CrossRef]

26. Suchman, M. Managing legitimacy: Strategic approaches and institutional approaches. Acad. Manag. Rev. 1995, 20, 571-610. [CrossRef]

27. Marques, A.C.; Fuinhas, J.A. Drivers promoting renewable energy: A dynamic panel approach. Renew. Sustain. Energy Rev. 2011, 15, 1601-1608. [CrossRef]

28. Shen, Y.-C.; Chou, C.J.; Lin, G.T.R. The portfolio of renewable energy sources for achieving the three E policy goals. Energy 2011, 336, 2589-2598. [CrossRef]

29. McKay, H. Environmental, economic, social and political drivers for increasing use of woodfuel as a renewable resource in Britain. Biomass Bioenergy 2006, 30, 308-315. [CrossRef]

30. Domac, J.; Richards, K.; Risovic, S. Socio-economic drivers in implementing bioenergy projects. Biomass Bioenergy 2005, 28 , 97-106. [CrossRef]

31. Ru, P.; Zh, Q.; Zhang, F.; Zhong, X.; Li, J.; Su, J. Behind the development of technology: Thetransition of innovation modes in China's wind turbine manufacturing industry. Energy Policy 2012, 43, 58-69. [CrossRef]

32. Céspedes-Lorente, J.; De Burgos-Jiménez, J.; Álvarez-Gil, M.J. Stakeholders' environmental influence: An empirical analysis in the Spanish hotel industry. Scand. J. Manag. 2003, 19, 333-358. [CrossRef]

33. Hawn, O.; Chatterji, A.; Mitchell, W. Two Coins in One Purse? How Market Legitimacy Affects the Financial Impact of Changes in Social Legitimacy: Addition Ad Deletion by the Dow Jones Sustainability Index; Working Paper; No. 2418300; Duke University: Durham, NC, USA, 2011.

34. DiMaggio, P.J.; Powell, W.W. The iron cage revisited: Institutional isomorphism and collective rationality in organizational field. Am. Sociol. Rev. 1983, 48, 147-160. [CrossRef]

35. Sung, B.; Song, W.-Y. Causality between public policies and exports of renewable energy technologies. Energy Policy 2013, 55, 95-104. [CrossRef]

36. Groba, F. Determinants of trade with solar energy technology components: Evidence on the Porter hypothesis? Appl. Econ. 2014, 46, 503-526. [CrossRef]

37. Jha, V. Trade Flows, Barriers and Market Drivers in Renewable Energy Supply Goods: The Need to Level the Playing Field; ICTSD Trade and Environment Issue Paper 10; International Centre for Trade and Sustainable Development: Geneva, Switzerland, 2009.

38. Wamsley, G.L.; Zald, M.N. The political economy of public organizations. Public Admin. Rev. 1973, 33, 62-73. [CrossRef]

39. Wamsley, G.L.; Zald, M.N. The Political Economy of Public Organizations; Indiana University Press: Bloomington, Indiana, 1976.

40. Arent, D.J.; Wise, A.; Gelman, R. The status and prospects of renewable energy for combating global warming. Energy Econ. 2011, 33, 584-593. [CrossRef]

41. Jaraité, J.; Kažukauskas, A. The profitability of electricity generating firms and policies promoting renewable energy. Energy Econ. 2013, 40, 858-865. [CrossRef]

42. Sung, B.; Choi, M.S.; Song, W.-Y. Exploring the effects of government policies on economic performance: Evidence using panel data for Korean renewable energy technology firms. Sustainability 2019, 11, 2253. [CrossRef]

43. Zhang, H.; Zheng, Y.; Zhou, D.; Zhu, D. Which subsidy mode improves the financial performance of renewable energy firms? A panel data analysis of wind and solar energy companies between 2009 and 2014. Sustainability 2015, 7, 16548-16560. [CrossRef] 
44. Zhang, H.; Li, L.; Zhou, D.; Zhou, P. Political connections, government subsidies and firm financial performance: Evidence from renewable energy manufacturing in China. Renew. Energy 2014, 63, 330-336. [CrossRef]

45. Cui, J.; Liu, X.; Sun, Y.; Yu, H. Can CDM projects trigger host countries' innovation in renewable energy? Evidence of firm-level dataset from China. Energy Policy 2020, 139, 111349. [CrossRef]

46. Hoppmann, J. The role of interfirm knowledge spillovers for innovation in mass-produced environmental technologies: Evidence from the solar photovoltaic industry. Organ. Environ. 2018, 31, 3-24. [CrossRef]

47. Plank, J.; Doblinger, C. The firm-level innovation impact of public R\&D funding: Evidence from the German renewable energy sector. Energy Policy 2018, 113, 430-438.

48. Sung, B. Do government subsidies promote firm-level innovation? Evidence from the Korean renewable energy technology industry. Energy Policy 2019, 132, 1333-1344. [CrossRef]

49. Costantini, V.; Crespi, F.; Martini, C.; Pennacchio, L. Demand-pull and technology-push public support for eco-innovation: The case of the biofuels sector. Res. Policy 2015, 44, 577-595. [CrossRef]

50. He, Z.-X.; Xu, S.-C.; Li, Q.-B.; Zhao, B. Factors that influence renewable energy technological innovation in China: A dynamic panel approach. Sustainability 2018, 10, 124. [CrossRef]

51. Johnstone, N.; Haŝčíč, L.; Popp, D. Renewable energy policies and technological innovation: Eevidence based on patent counts. Environ. Resour. Econ. 2010, 45, 33-155. [CrossRef]

52. Peters, M.; Schneider, M.; Griesshaber, T.; Hoffmann, V.H. The impact of technology-push and demand-pull policies on technical change-Does the locus of policies matter? Res. Policy 2012, 41, 1296-1308. [CrossRef]

53. MOTIC. Competitiveness Enhancement Plan of Renewable Energy Technology Industry. Ministry of Trade, Industry and Energy; MOTIC: Sejong City, Korea, 2019.

54. MOTIC. 2020 Action Plan for Development, Utilization and Distribution of Renewable Energy Technologies. Ministry of Trade, Industry and Energy; MOTIC: Sejong City, Korea, 2020.

55. Dechezleprêtre, A.; Glachant, M.; Haščič, I.; Johnstone, N.; Ménière, Y. Invention and transfer of climate change-mitigation technologies: A global analysis. Rev. Environ. Econ. Policy 2011, 5, 109-130. [CrossRef]

56. Dasgupta, S.; Hong, J.H.; Laplante, B.; Mamingi, N. Disclosure of environmental violations and stock market in the Republic of Korea. Ecol. Econ. 2006, 58, 759-777. [CrossRef]

57. Aden, J.; Ahn, K.-H.; Rock, M.T. What is driving the pollution abatement expenditure behavior of manufacturing plants in Korea? World Dev. 1999, 27, 1203-1214. [CrossRef]

58. Moon, T.H. Sustainable development in Korea, key issues and government response. Int. Rev. Public Admin. 2006, 11, 1-18. [CrossRef]

59. Lee, M.-H. The effect of environmental regulations: A restricted cost function for Korean manufacturing industries. Environ. Dev. Econ. 2007, 12, 91-104. [CrossRef]

60. MOE (Ministry of Environment). 2010 White Paper of Environment; Seoul MOE: Sejong City, Korea, 2010.

61. Irfan, M.; Zhao, Z.-Y.; Li, H.; Rehman, A. The influence of consumers' intention factors on willingness to pay for renewable energy: A structural equation modelling approach. Environ. Sci. Pollut. Res. 2020, 27, 21747-21761. [CrossRef]

62. Lund, P.D. Effects of energy policies on industry expansion in renewable energy. Renew. Energy 2009, 34, 53-64. [CrossRef]

63. Hanel, P.; St-Pierre, A. Effects of R\&D spillover or the profitability of firms. Rev. Ind. Organ. 2002, 20, 305-322.

64. Zouaghi, F.; Sánchez, M.; Martínez, M.G. Did the global financial crisis impact firms' innovation performance? The role of internal and external knowledge capabilities in high and low tech industry. Technol. Forecast. Soc. 2018, 132, 92-104. [CrossRef]

65. OECD. Supporting Investment in Knowledge Capital, Growth and Innovation; OECD: Paris, France, 2013.

66. Ruzzier, M.; Ruzzier, M.K. On the relationship between firm size, resource, age at entry and internationalization: The case of Slovenian SMEs. J. Bus. Econ. Manag. 2015, 16, 52-73. [CrossRef]

67. Argote, L.; Miron-Spektor, E. Organizational learning: From experience to knowledge. Organ. Sci. 2011, 32, 1121-1367. [CrossRef]

68. Chen, G.; Zhou, Q.; Liu, W. Organizational learning from experience: Current status in multilevel perspective, integration model and future direction. Nankai Bus. Rev. Int. 2017, 8, 122-157. [CrossRef]

69. Balasubramanian, N.; Lee, J. Firm age and innovation. Ind. Corp. Chang. 2008, 17, 1019-1047. [CrossRef]

70. Criscuolo, P.; Nicolaou, N.; Salter, A. The elixir (or burden) of youth? Exploring differences in innovation between start-ups and established firms. Res. Policy 2012, 41, 319-333. [CrossRef]

71. Sorensen, J.B.; Stuart, T.E. Aging, obsolescence and organizational innovation. Admin. Sci. Quart. 2000, 45, 81-112. [CrossRef]

72. Delmas, M.; Toffel, M.W. Stakeholders and environmental management practices: An institutional framework. Bus. Strateg. Environ. 2004, 13, 209-222. [CrossRef]

73. Porter, M.E.; Van der Linde, C. Toward a New Conception of the Environment-Competitiveness Relationship. J. Econ. Perspect. 1995, 9, 97-118. [CrossRef]

74. Jaffe, A.B.; Palmer, K. Environmental regulation and innovation: A panel data study. Rev. Econ. Stat. 1997, 79, 610-619. [CrossRef]

75. Jaffe, A.B.; Newell, R.G.; Stavins, R.N. A tale of two market failures: Technology and environmental policy. Ecol. Econ. 2005, 54, 164-174. [CrossRef]

76. Broocks, A.; Van Biesebroeck, J. The impact of export promotion on export market entry. J. Int. Econ. 2017, 107, 19-33. [CrossRef]

77. Van Biesebroeck, J.; Yu, E.; Chen, S. The impact of trade promotion services on Canadian exporter performance. Can. J. Econ. 2015, 48, 1481-1512. [CrossRef] 
78. Martinez-Roman, J.A.; Gamero, J.; Amayo, J.A. Analysis of innovation in SMEs using an innovative capacity-based non-linear model: A study in the province of Seville (Spain). Technovation 2011, 31, 459-475. [CrossRef]

79. Lewis, J.I.; Wiser, R.H. Fostering a renewable energy technology industry: An international comparison of wind industry policy support mechanisms. Energy Policy 2007, 35, 1844-1857. [CrossRef]

80. Sawhney, A.; Kahn, M.E. Understanding cross-national trends in high-tech renewable power equipment exports to the United States. Energy Policy 2012, 46, 308-318. [CrossRef]

81. Kohli, A.K.; Jaworski, B.J. Market orientation: The construct, research pro-positions, and managerial implications. J. Mark. 1990, 54, 1-18. [CrossRef]

82. Morgan, N.A.; Zou, S.; Vorhies, D.W.; Katsikeas, C.S. Experiential and informational knowledge, architectural marketing capabilities, and the adaptive performance of export ventures: A cross-national study. Decis. Sci. 2003, 34, 287-321. [CrossRef]

83. Murray, J.Y.; Gao, G.Y.; Kotabe, M. Market orientation and performance of export ventures: The process through marketing capabilities and competitive advantages. J. Acad. Mark. Sci. 2011, 39, 252-269. [CrossRef]

84. Verwaal, E.; Donkers, B. Firm size and export intensity: Solving an empirical puzzle. J. Int. Bus. Stud. 2002, 33, 603-613. [CrossRef]

85. Podsakoff, P.M.; MacKenzie, S.B.; Lee, J.Y.; Podsakoff, N.P. Common method biases in behavioral research: A critical review of the literature and recommended remedies. J. Appl. Psychol. 2003, 88, 879-903. [CrossRef] [PubMed]

86. Rodríguez-Ardura, I.; Meseguer-Artola, A. Editorial: How to prevent, detect and control common method variance in electronic commerce research. J. Electron. Comer. Res. 2020, 15, I-IV. [CrossRef]

87. Harman, H.H. Modern Factor Analysis; University of Chicago Press: Chicago, IL, USA, 1976.

88. Hair, J.F.; Anderson, R.L.; Tatham, W.C. Multivariate Data Analysis with Reading; Prentice-Hall: Upper Saddle River, NJ, USA, 1998.

89. Hoyle, R.H. Structuring Equation Modeling: Concepts, Issues and Applications; Sage Publication: London, UK, 1995.

90. Hair, J.F.; Black, W.C.; Babin, B.J.; Anderson, R.F. Multivariate Data Analysis: A Global Perspective, 7th ed.; Prentice Hall: Upper Saddle River, NJ, USA, 2009.

91. Bentler, P.M.; Bonett, D.G. Significance tests and goodness of fit in the analysis of covariance structures. Psychol. Bull. 1980, 88 , 588-606. [CrossRef]

92. Kline, R.B. Principles and Practice of Structural Equation Modelling, 2nd ed.; Guilford Press: New York, NY, USA, 2005.

93. Thompson, B. Exploratory and Confirmatory Factor Analysis: Understanding Concepts and Applications; American Psychological Association: Washington, DC, USA, 2004.

94. Bagozzi, R.P.; Yi, Y. On the evaluation of structural equation models. J. Acad. Market. Sci. 1998, 16, 74-94. [CrossRef]

95. Fornell, C.; Larcker, D.F. Evaluating structural equation models with unobservable variables and measurement error. J. Mark. Res. 1981, 18, 39-50. [CrossRef]

96. Dechezleprétre, A.; Sato, M. The impact of environmental regulations on competitiveness. Rev. Env. Econ. Policy 2017, 11, 183-206. [CrossRef]

97. Dimos, C.; Pugh, G. The effectiveness R\&D subsidies: A meta-regression analysis of the evaluation literature. Res. Policy 2016, 45, 797-815.

98. Ang, G.; Rottgers, D.; Burli, P. The Empirics of Enabling Investment and Innovation in Renewable Energy. In OECD Environment Working Papers; No. 123; OECD: Paris, France, 2017.

99. Chang, K.; Zeng, Y.; Wang, W.; Wu, X. The effects of credit policy and financial constraints on tangible and research and development investment: Firm level evidence from China's renewable energy industry. Energy Policy 2019, 130, 438-447. [CrossRef]

100. Milanés-Montero, P.; Arroyo-Farrona, A.; Pérez-Calderó, E. Assessment of the influence of feed-in tariffs on the profitability of European photovoltaic companies. Sustainability 2018, 10, 3427. [CrossRef]

101. Ma, R.; Cai, H.; Ji, Q.; Zhai, P. The impact of feed-in tariff degression on R\&D investment in renewable energy: The case of the solar PV industry. Energy Policy 2021, 151, 112209.

102. Han, D.; Baek, S. Status of renewable capacity for electricity generation and future prospect in Korea: Global trends and domestic strategies. Renew. Sustain. Energy Rev. 2017, 76, 1524-1533. [CrossRef]

103. Yoon, J.-H.; Sim, K.-H. Why is South Korea's renewable energy policy failing? A qualitative evaluation. Energy Policy 2015, 86, 369-379. [CrossRef]

104. International Energy Agency (IEA). Korea 2020 Energy Policy Review; IEA Country Report: Paris, France, 2021.

105. Aghion, P.; Harris, C.; Vickers, J. Competition, imitation and growth with step-by-step innovation. Rev. Econ. Stud. 2011, 68, 467-492. [CrossRef]

106. Ahn, S. Competition, Innovation and Productivity Growth: A Review of Theory and Evidence. In OECD Economics Department Working Papers; No. 317; OECD: Paris, France, 2002. 